\title{
Thyroid hormone receptor actions on transcription in amphibia: The roles of histone modification and chromatin disruption
}

\author{
Yun-Bo Shi ${ }^{{ }^{*}}$, Kazuo Matsuura ${ }^{1}$, Kenta Fujimoto ${ }^{2}$, Luan Wen ${ }^{1}$ and Liezhen Fu ${ }^{1}$
}

\begin{abstract}
Thyroid hormone (T3) plays diverse roles in adult organ function and during vertebrate development. The most important stage of mammalian development affected by T3 is the perinatal period when plasma T3 level peaks. Amphibian metamorphosis resembles this mammalian postembryonic period and is absolutely dependent on T3. The ability to easily manipulate this process makes it an ideal model to study the molecular mechanisms governing T3 action during vertebrate development. T3 functions mostly by regulating gene expression through T3 receptors (TRs). Studies in vitro, in cell cultures and reconstituted frog oocyte transcription system have revealed that TRs can both activate and repress gene transcription in a T3-dependent manner and involve chromatin disruption and histone modifications. These changes are accompanied by the recruitment of diverse cofactor complexes. More recently, genetic studies in mouse and frog have provided strong evidence for a role of cofactor complexes in T3 signaling in vivo. Molecular studies on amphibian metamorphosis have also revealed that developmental gene regulation by $\mathrm{T} 3$ involves histone modifications and the disruption of chromatin structure at the target genes as evidenced by the loss of core histones, arguing that chromatin remodeling is an important mechanism for gene activation by liganded TR during vertebrate development.
\end{abstract}

Keywords: Transcriptional coactivator, Corepressor, Thyroid hormone receptor, Stem cell, Apoptosis, Metamorphosis, Xenopus laevis and tropicalis, Histone methylation, Histone acetylation, Nucleosome removal

\section{Introduction}

Thyroid hormone (T3) affects numerous biological processes in vertebrates and thyroid diseases are arguably the most prevalent group of metabolic disorders in the world [1-3]. In the adult mammals such as humans, T3 deficiency leads to reduced metabolic rate while both hyperthyroidism and hypothyroidism result in abnormal function of diverse organs and tissues [4-6].

T3 plays a critical role for vertebrate development. T3 deficiency during human development leads to a number of developmental defects, including the formation of a goiter, i.e., a lump in the neck due to enlarged thyroid gland, and cretinism, which is manifested with severe mental deficiency and short stature $[7,8]$. Similar requirement

\footnotetext{
* Correspondence: Shi@helix.nih.gov

'Section on Molecular Morphogenesis, Program in Cellular Regulation and Metabolism (PCRM), Eunice Kennedy Shriver National Institute of Child Health and Human Development (NICHD), National Institutes of Health (NIH), Bethesda, Maryland 20892, USA

Full list of author information is available at the end of the article
}

for T3 is also observed in other vertebrates. The most dramatic T3-regulated developmental process is anuran metamorphosis, when an aquatic tadpole is transformed into a terrestrial frog, as first demonstrated a century ago [9-11]. This process resembles the postembryonic, or perinatal development in mammals when plasma $\mathrm{T} 3$ levels also peak [12].

T3 can exert its effects at both the genomic level through nuclear T3 receptors (TRs) and the non-genomic levels. The non-genomic effects of $\mathrm{T} 3$ involve the binding of $\mathrm{T} 3$ to diverse cellular proteins. Among them include the cell surface integrin $\alpha \mathrm{V} \beta 3$, better known as a receptor for the extracellular matrix, and a number of cytosolic proteins, which have additional, often enzymatic functions [13-19]. In addition, while TRs are predominantly localized in the nucleus even in the absence of $\mathrm{T} 3$, some are present in the cytoplasm. Interestingly, cytosolic TR $\beta$ can form a complex with the signaling kinase MAPK, which may be responsible for the rapid activation of MAPK by T3 [19], and

\section{Biomed Central}


unliganded TR $\beta$ can interact with phosphatidylinosital 3 kinase (PI3K) to activate this signaling pathway [20,21], suggesting that cytoplasmic TR may mediate some nongenomic effect of T3.

The genomic action of T3, i.e., transcriptional regulation through TR, is believed to be the main function of T3 under most physiological and pathological conditions. There are two TR genes in vertebrates, TR $\alpha$ and TR $\beta$ genes, encoding two highly homologous proteins with high affinity binding to T3, that can differ in their tissue and temporal expression [22]. Mutations in TR $\beta$ have long been shown to be responsible for the human syndrome "resistance to T3" or RTH [23-25]. Most of these TR $\beta$ mutants have reduced or abolished ability to bind to T3. More recently, human patients due to mutated TR $\alpha$ genes were reported, with the mutations causing resistance to T3 but have a different phenotype than patients that have mutations in TR $\beta[26,27]$. The importance of TRs in mediating T3 effects has also been substantiated by a large number of gene knockout and transgenic studies in mice $[23,28]$. Additionally, the total dependence of amphibian metamorphosis on T3 has allowed us and others to show that TR is both necessary and sufficient to mediate the metamorphic effects of T3 [29-40], demonstrating an essential role of TR in T3 signaling during development.

\section{Gene regulation by TR}

T3 can both activate and repress target gene transcription through TRs. TRs are transcription factors belonging to the nuclear hormone receptor superfamily that also include steroid hormone receptors, 9-cis retinoic acid receptors (RXRs), as well as a number of orphan receptors which lack ligands or whose ligands remain to be identified [2,22,41-43]. Like most other members of this family, TRs bind to specific DNA elements called T3 response elements or TREs and regulate target genes bearing such elements in a ligand-dependent manner. TRs are mostly localized in the nucleus even in the absence of T3 and can bind to TREs both in the presence and absence of T3 to regulate target gene transcription. TRs can function as monomers, homodimers, as well as heterodimers with RXRs. For genes induced by T3, TR/RXR heterodimers bind to TREs in target genes even in the context of chromatin [44]. At the unliganded state, the heterodimers represses the target promoter and when $\mathrm{T} 3$ is available, the liganded TR/RXR heterodimers then activate the same promoters [2,41-46]. For genes that are down-regulated by T3, the opposite is true. However, relatively few T3 downregulated genes have been studied and less is known about how T3 represses these genes. Thus, we will focus here only on T3-induced gene expression.

TR can recruit corepressor or coactivator complexes to the T3-inducible promoters in the absence or presence of T3, respectively (Figure 1). Many TR-interacting proteins and complexes have been isolated and characterized over the years [2,47-67]. The best-studied TR-corepressors are two highly related proteins N-CoR (nuclear corepressor) and SMRT (silencing mediator of retinoid and thyroid hormone receptors). They form large histone deacetylase (HDAC) 1 or HDAC3-containing complexes, although most evidence suggests that unliganded TR recruits only HDAC3-containing complexes (Table 1) [48-52,54,64, 68-77]. Thus, transcriptional repression by unliganded TR likely involves histone deacetylation.

T3 binding to TR triggers the release of corepressor complexes and recruitment of coactivator complexes. In vitro and cell culture studies as well as analyses in the reconstituted frog oocytes, where one can study the regulation of chromatinized template, have shown that T3 induces the recruitment of diverse coactivator complexes including ATP-dependent chromatin remodelers, histone acetyltransferase/methyltransferase-containing complexes, as well as TRAP/DRIP/mediator complex (Figure 1) (Table 1) [2,53-60,65-67,78-89], suggesting that gene activation by TR involves histone acetylation and/or methylation as well as chromatin remodeling.

The involvement of these cofactors in T3 signaling during development has been more difficult to substantiate as cofactor knockout mice often have relatively mild phenotypes due to cofactor redundancy or embryonic lethal phenotypes, thus revealing little information about their roles in development. In addition, when gene knockout and transgenesis result in easily identifiable phenotypes, such as mice deficient in N-CoR, p300 (an acetyltransferase), SRC1-3 (steroid receptor coactivator 1, 2, 3, acetyltransferases), or TRAP220 (the TR-binding component of the TRAP complexes) [90-95], the wide involvement of these cofactors in the gene regulation by other transcription factors has made it difficult to link any of the effects directly to T3 signaling defects. Despite these, accumulating evidence has supported roles of some of the cofactors in T3 signaling. One of the earliest was the insensitivity to T3 of the SRC1 knockout mice [96]. More recently, mutations have been introduced to the endogenous $\mathrm{N}-\mathrm{CoR}$ and SMRT genes in mice and found to cause derepression of T3-inducible genes, supporting their roles in gene repression by unliganded TR [97-99].

The dependence of amphibian metamorphosis on T3 and the ability to manipulate this process have enabled extensive studies on the involvement of cofactors in T3 signaling in vivo. Chromatin immunoprecipitation (ChIP) assays on tadpole tissues have shown that TR recruits corepressor complexes to endogenous T3-inducible genes in premetamorphic Xenopus laevis tadpoles when T3 is absent $[31,77,100]$. More importantly, interfering corepressor function by overexpressing a dominant negative $\mathrm{N}$-CoR that contains only the TR interacting domain of 


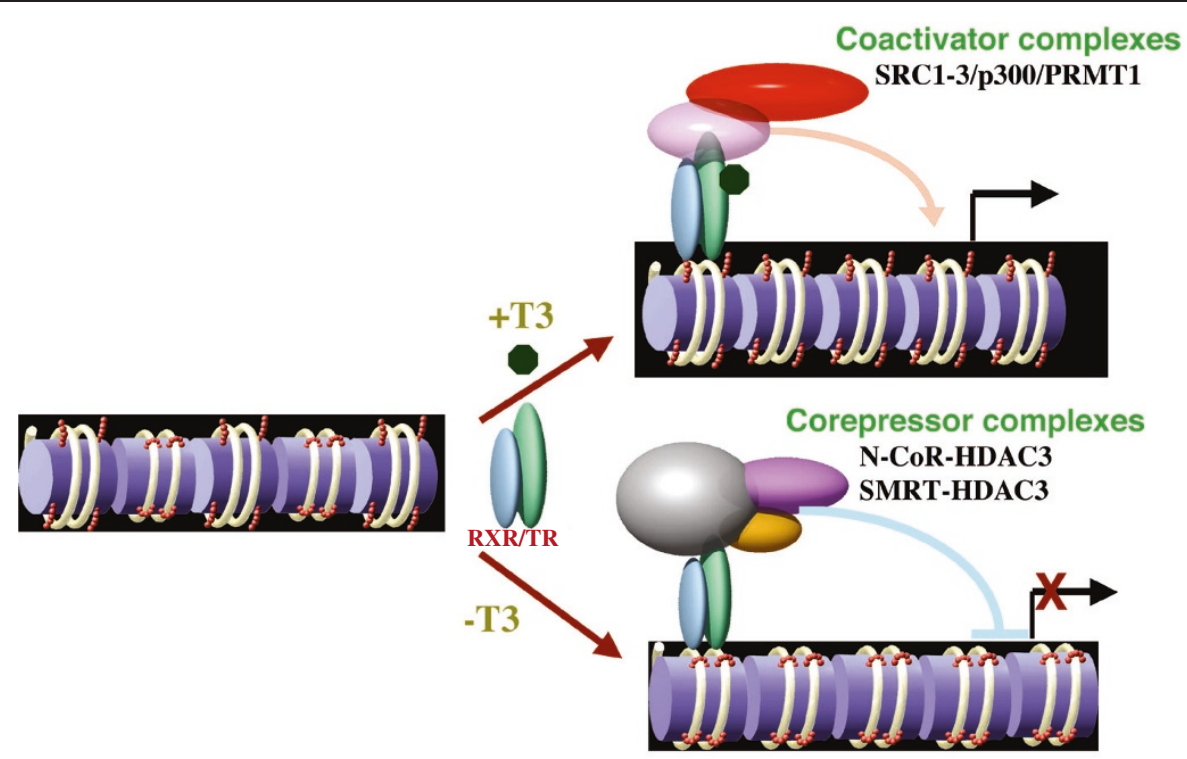

Figure 1 A model for gene regulation by TR. In the absence of T3, TR forms heterodimers with RXR (9-cis retinoic acid receptor) and the heterodimer binds to the T3 response elements (TREs) in the target genes to repress their expression by recruiting corepressor complexes such as those containing the related protein N-CoR or SMRT and HDAC-3. When T3 is present, the corepressor complexes are released upon T3 binding to TR, and coactivator complexes such as those containing SRC, p300, and PRMT1, are recruited. SRC and p300 are histone acetyltransferases and PRMT1 is a histone methyltransferase.

Xenopus laevis $\mathrm{N}$-CoR leads to premature upregulation of T3-inducible genes and precocious metamorphosis [101], demonstrating an important role of corepressor recruitment by unliganded TR during development.

When T3 is present either endogenously or by adding it to the tadpole rearing water, the corepressor complexes are released and coactivator complexes, such as those containing histone acetyltransferases SRC3 and p300 and histone methyltransferase PRMT1 (protein arginine methyltransferase 1 ) are recruited by TR, accompanying the activation of target genes and metamorphosis [84,86-89]. The critical role of coactivators SRC1-3 and p300 in T3 signaling during metamorphosis is supported by transgenic studies. SRCs bind to liganded TR directly and interact with p300 and PRMT1 to form large coactivator complexes. Xenopus laevis SRC3 is upregulated during

Table 1 Known histone modification enzymes involved in gene regulation by Xenopus TR

\begin{tabular}{llll}
\hline Cofactor & Histone modification & Gene regulation & Reference \\
\hline HDAC3 & Deacetylation & Repression & {$[68,76,77]$} \\
SUV39H1 & H3K9 methylation & Repression & {$[74,75]$} \\
G9a & H3K9 methylation & Repression & {$[73,74]$} \\
SRC & Acetylation & Activation & {$[55,86-88]$} \\
P300 & Acetylation & Activation & {$[55,86,89]$} \\
CARM1 & H3R17 methylation & Activation & {$[85]$} \\
PRMT1 & H4R3 methylation & Activation & {$[84]$} \\
\hline
\end{tabular}

metamorphosis [102] and is recruited to target genes by liganded TR in a gene- and tissue-specific manner during metamorphosis [88]. Furthermore, transgenic overexpression of a dominant negative Xenopus laevis SRC3 that contained only the TR-binding domain inhibited both gene activation by T3 and metamorphosis [87], indicating that coactivator recruitment is essential for liganded TR function during metamorphosis.

As the dominant negative SRC3 blocked all coactivator binding to liganded TR, the roles of specific coactivator complexes remained unclear. Interestingly, transgenic overexpression of a dominant negative p300 that contained only the SRC-interacting domain also blocked gene activation and metamorphic changes during either T3-induced or natural metamorphosis [89]. Since this mutant p300 does not interfere with the binding of liganded TR with coactivators directly and only disrupts SRC-p300 interaction, the findings argue that SRC-p300 coactivator complexes or related ones are required for the developmental function of liganded TR. Further support for a role of the SRC-p300 complexes in metamorphosis came from transgenic overexpression of another component of the complexes, PRMT1. Overexpression of wild type PRMT1 enhances TR binding to endogenous target genes, gene activation induced by $\mathrm{T} 3$, and the rate of metamorphic progression [84]. Thus corepressor and coactivator complexes play distinct roles in regulating T3-target genes to affect different stages of animal development. 


\section{Chromatin disruption by liganded TR}

Unlike steroid hormone receptors, TR is predominantly localized in the nucleus even in the absence of T3 and associated with chromatin [103]. Studies in the frog oocyte transcription system, where the exogenous DNA injected into the nucleus is chromatinized, offered the first evidence for direct binding of unliganded TR to a TRE in chromatin [44,104]. Interestingly, when the structure of the minichromosome assembled in the Xenopus laevis oocyte was analyzed, it was found that T3 induced the disruption of the ordered nucleosomal organization in the minichromosome in the presence but not in the absence of TR (Figure 2) [44,45,105]. This disruption required DNA binding domain of the TR (Figure 2A), indicating that TR has to bind the TRE to mediate the disruption. By using a supercoiling assay for a circular plasmid, it was shown that the liganded TR-induced chromatin disruption was equivalent to the loss of 2-3 nucleosomes per receptor binding locus (Figure 2B) [45,105]. While the underlying mechanism for the chromatin remodeling remains to be determined, it has been shown that liganded TR recruits chromatin remodeling complexes containing Brg1 and BAF57 to the TRE of the reporter gene [55,78]. Thus, it is likely that such remodeling complexes participate in the removal of the nucleosome near the TRE, thus facilitating the assembly of the transcriptional machinery at the promoter region.

More recently we have investigated chromatin changes in vivo by using the model system of intestinal remodeling during metamorphosis in Xenopus tropicalis, a species highly related to the well-studied Xenopus laevis [106,107]. Intestinal remodeling involves the degeneration of larval epithelium and concurrent do novo development of the adult epithelial stem cells, followed by their proliferation

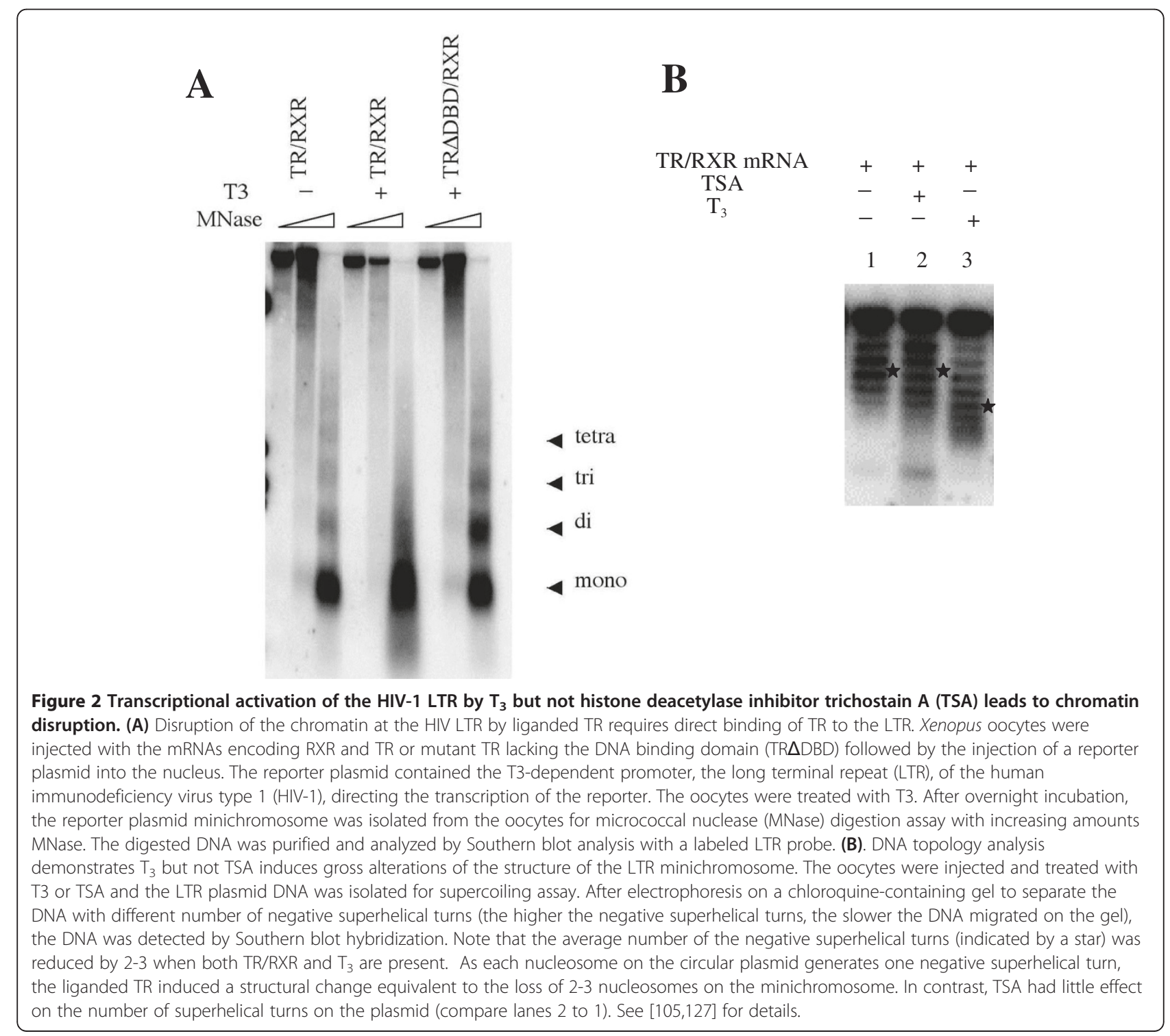


and differentiation into the adult epithelium [108-110]. This process resembles the maturation of the mammalian intestine during perinatal development when plasma T3 level is high $[111,112]$. The simplicity and cell composition of the intestine has made it a valuable model to study the mechanism of TR action during development. By using ChIP assay with antibodies again core histones $\mathrm{H} 2 \mathrm{~B}$ and $\mathrm{H} 3$, we have recently shown that during either T3-induced or natural metamorphosis, T3 induces the removal of core histones from the TRE regions of T3 response genes, including $\mathrm{TR} \beta$, in the Xenopus tropicalis intestine, accompanying increased TR binding and recruitment of RNA polymerase II (Figure 3A) [113]. This finding suggests local removal of nucleosomes by liganded TR, consistent with the observations in the frog oocyte transcription system. Interestingly, both Brg1 and BAF57, component of the Brg1-containing chromatin remodeling complex, are upregulated or expressed during metamorphosis in Xenopus laevis [78], suggesting that the nucleosome removal during intestinal metamorphosis involve the recruitment of this complex by liganded TR.

\section{T3-induced histone modifications at target genes}

The recruitment by TR of a number of cofactor complexes containing histone modification enzymes implicates a role of histone modification in gene regulation by TR. Studies in the frog oocyte showed early on that HDAC activity and chromatin assembly were both required for efficient
A
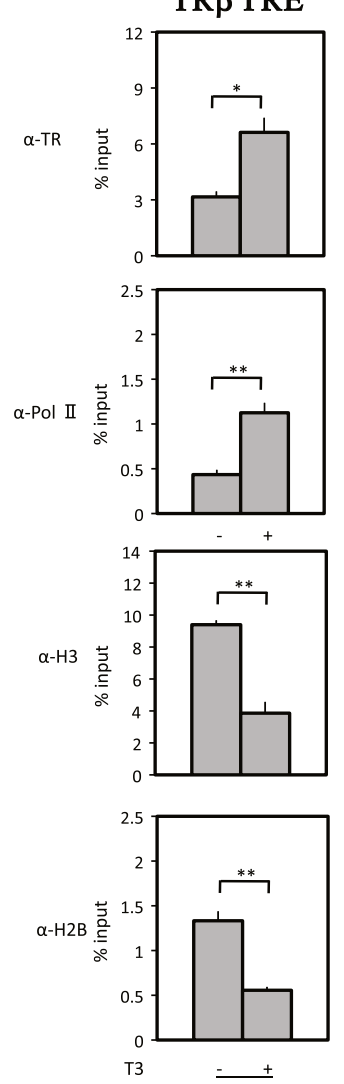

TRß Exon 5
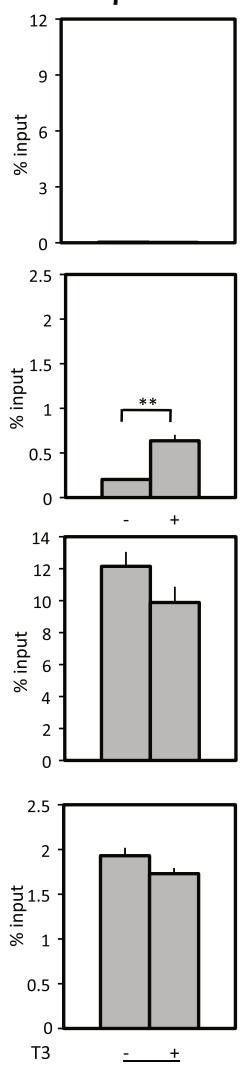

B
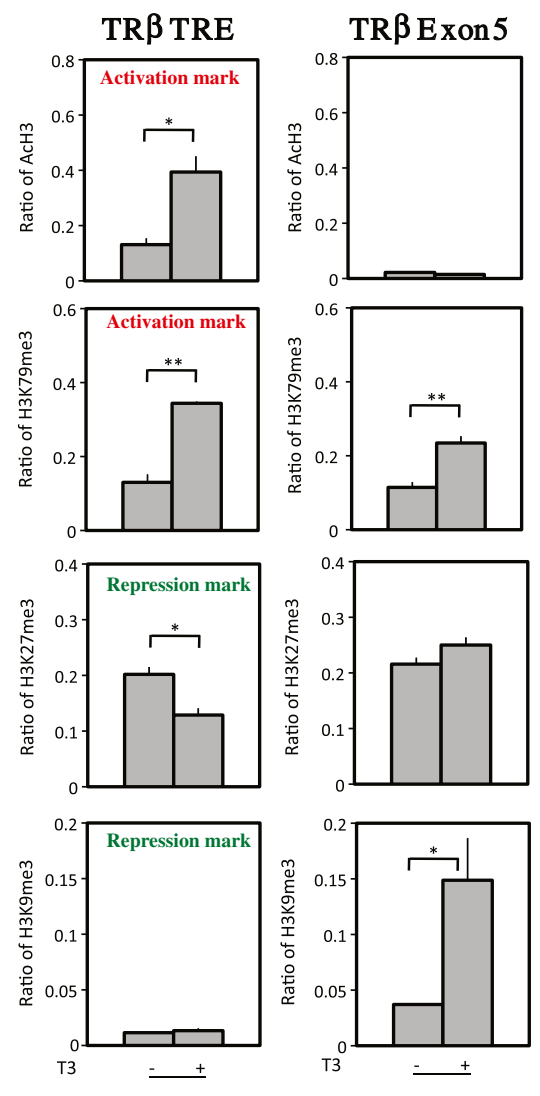

Figure 3 (A) TR binding to the target gene TR $\beta$ leads to the recruitment of RNA polymerase a (Pol II) and loss of core histones during T3-induced metamorphosis in Xenopus tropicalis intestine. Tadpoles at stage 54 were treated with or without T3 for 2 days, and the intestine was isolated for ChIP assay with anti-TR, anti-Pol a, anti-H3, or anti-H2B antibody. The immunoprecipitated DNA was analyzed by qPCR for the presence of the TRE region of the TR $\beta$ promoter or a region of TR $\beta$ exon 5 as a negative control. Note that TR is bound to the promoter but not the exon 5 in the absence of T3 in premetamorphic tadpoles. In the presence of T3, TR binding to the TREs was increased at the promoter, accompanied by the recruitment Pol II and reduction in total histones at the TRE region. Increased Pol II was also observed in the exon region due to increased transcription in the presence of T3. Error bars indicate s.e.m. $(n=3)$. The one and two stars indicate pairs of samples with significant differences, $p<0.05$ and $p<0.01$, respectively. (B). Changes in all histone activation marks but only one of the two repression marks correlate with gene activation by liganded TR. Premetamorphic tadpoles at stage 54 were treated with T3 for 2 days. The intestine was isolated and subjected to ChIP assay with anti-AcH3, anti-H3K79me3, anti-H3K27me3 or anti-H3K9me3 antibody. ChIP signals were normalized with the ChIP signals of histone $\mathrm{H} 3$ in $(\mathbf{A})$ for the corresponding promoter/exon regions. Error bars indicate s.e.m. $(n=3)$. The one and two stars indicate pairs of samples with significant differences, $p<0.05$ and $p<0.01$, respectively. See [113] for details. 
promoter repression by unliganded TR in vivo [46,114]. ChIP assays with antibodies against acetylated histones showed that T3 treatment or blocking HDAC activity leads to increased histone acetylation at T3-target genes both in mammalian cell cultures and frog oocytes as well as during frog metamorphosis [114-117]. More importantly, treatment of premetamorphic tadpoles with a histone deacetylase inhibitor leads to precocious induction of T3 response genes in the absence of $\mathrm{T} 3$, supporting a role of deacetylase in gene repression by unliganded TR in premetamorphic tadpoles [118,119].

In addition to histone acetylation, histone methylation and phosphorylation have also been implicated to play a role in gene regulation by $\mathrm{TR}$ in the frog oocyte transcription system [75]. During Xenopus tropicalis metamorphosis, gene activation by TR is accompanied by changes in the methylation levels of various histone residues [113,120,121] (Figure 3B). Bilesimo et al. [120] observed that in the brain and tail fin of tadpoles treated with $\mathrm{T} 3$, gene activation by $\mathrm{T} 3$ was associated with distinct patterns of histone methylations and that gene-specific patterns of TR binding to target genes correlated with gene-specific modifications of H3K4 methylation. Furthermore, treatment of tadpole tail fin with an inhibitor of histone demethylases led to increased T3-response gene expression and TR binding to TREs, supporting a role of histone methylation in gene regulation by T3. In our own studies on intestinal remodeling during metamorphosis, we observed that of the three activation histone methylation marks analyzed, all were increased upon gene activation by T3 (Figure 3B) [113]. In contrast, of the two repression histone methylation marks analyzed, only one was reduced upon gene activation by T3 while the other did not change at the TRE region and was increased in the downstream transcribed region (Figure 3B) [113]. As the activation and repression marks were defined based on correlations with gene expression levels in cultured cells, these findings suggest that tissue and/or developmental context may affect the utilization of histone modification patterns in vivo.

T3 induces changes in histone modifications at target genes presumably by recruiting different cofactor complexes via TRs. ChIP assays have shown that during Xenopus laevis or tropicalis metamorphosis, increased histone acetylation correlates with the activation of T3 target genes (Figure 3B), the release of corepressors and the recruitment of coactivators [31,77,86-89,100,113,117,120]. Furthermore, transgenic studies have shown that the recruitment of coactivator complexes containing acetyltransferases SRC3 and p300 or related complexes is essential for the histone acetylation, gene activation and metamorphosis [87-89], demonstrating a role of histone acetyltransferasecontaining coactivator complexes in T3 signaling during development.
The increase in histone methylation at T3 target genes during metamorphosis is likely due to the recruitment of histone methyltransferases. At least three histone methyltransferases, CARM1 (coactivator-associated arginine methyltransferase 1), PRMT1, and Dot1L (Dot1-like), have been shown to be expressed during metamorphosis in Xenopus laevis or tropicalis [84,85,122]. Among them, Dot1L is induced by T3 during metamorphosis directly at the transcription level [122], while PRMT1 is indirectly induced by T3 via the induction of c-Myc gene $[84,123]$. PRMT1 is known to be associated with the SRC-p300 complexes and is recruited to T3 target genes during metamorphosis [84]. More importantly, transgenic overexpression of PRMT1 leads to increased expression of T3 target genes and accelerated metamorphosis [84,124], supporting a role of PRMT1 in T3 signaling. Dot1L is the only known histone methyltransferase capable of methylating H3K79, which is correlated with gene activation by T3 (Figure 3B) [113]. Thus, T3 activates the Dot1L gene, and Dot1L in turn feeds back positively on liganded TR function during metamorphosis by methylating H3K79 at T3 target genes.

\section{Conclusion}

T3 has long been known to be critical for human development, mainly due to its effect on perinatal development. The developmental mechanisms of T3 action, however, have been more difficult to decipher in mammals. Amphibian metamorphosis offers an opportunity to dissect the function and associated mechanisms of T3 action during development without the complication of maternal influences. This has enabled the demonstration of dual function roles of TR during development [33]. More importantly, studies in frogs were the first to provide in vivo evidence for the requirement cofactors in TR function in development. More recent studies in cell cultures, frog oocytes, as well as during metamorphosis, have shown that during vertebrate development, when T3 is absent or at low levels, TR/RXR heterodimers recruit corepressor complexes at T3 inducible genes to establish a repressive chromatin structure in part by using repression histone marks (Figure 4). When T3 becomes available, the corepressor complexes are removed and coactivator complexes are recruited. These complexes help to disrupt the ordered chromatin structure, causing local release of nucleosomes and increases in the levels of activation histone marks (Figure 4). Consequently genes are activated and the developmental effects of T3 are transduced toward downstream events. Clearly, many important questions remain to be addressed. Of immediate interests are the roles of different histone modification enzymes and chromatin remodeling complexes in tissue- and gene-specific regulation of 

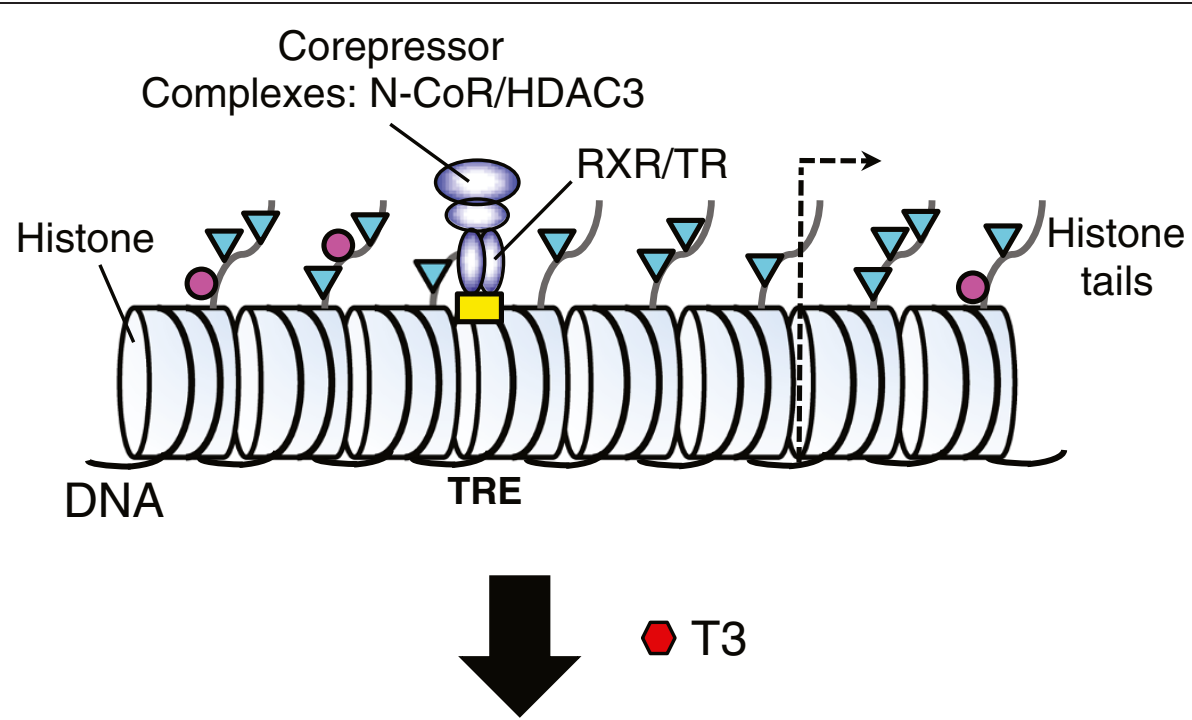

Coactivator

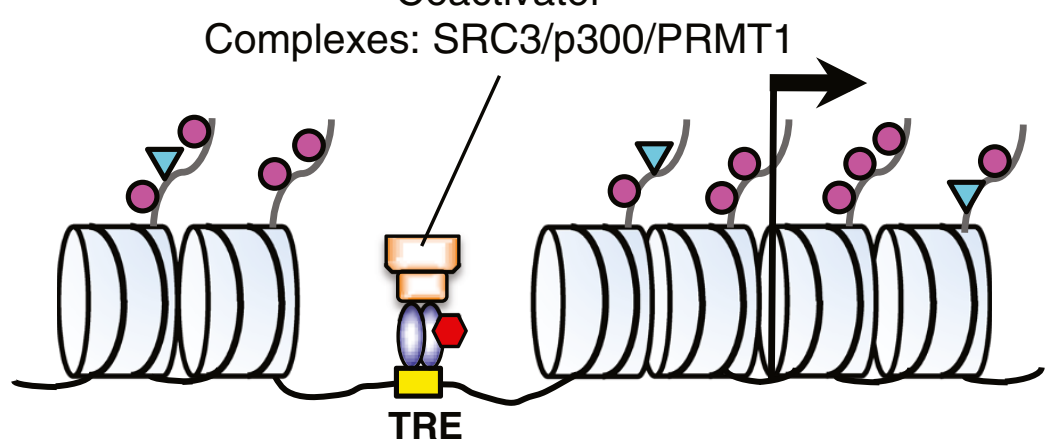

$\nabla$ Repression mark

\section{Activation mark}

Figure 4 A model for gene regulation by TR. T3 functions by regulating gene transcription through T3 receptors (TRs). In the absence of T3, TR/RXR heterodimer binds to TREs in the target genes and recruits corepressor complexes such as the N-CoR-HDAC3 complex. This leads to the establishment of a repressed chromatin state with ordered nucleosomal arrays and abundant repression marks. When T3 is present, TR/RXR recruits coactivator complexes such as those containing SRC, p300, and PRMT1. This leads to the loss of nucleosomes and modifications of the histone tails, leading to gene activation. See [113] for details.

target genes, which is likely critical for tissue specific effects of T3 during development. Are different enzymes recruited by TR in a gene- and tissuespecific manner during development? Do different cofactors affect the utilization and function of other cofactors? While histone modifications have been correlated with gene regulation, are or how are they required for gene regulation by $\mathrm{T} 3$ and vertebrate development? The ability to manipulate amphibian metamorphosis will no doubt ensure that this model will continue to serve well the mechanistic studies on TR function in vivo in the foreseeable future, especially in light of the recent advancement in gene knockout studies in Xenopus [125,126].
Competing interests

The authors declare that they have no competing interests.

\section{Authors' contributions}

All authors participated in the writing of the review. All authors read and approved the final manuscript.

\section{Acknowledgement}

This research was supported in part by the Intramural Research Program of $\mathrm{NICHD}, \mathrm{NIH}$.

\section{Author details}

${ }^{1}$ Section on Molecular Morphogenesis, Program in Cellular Regulation and Metabolism (PCRM), Eunice Kennedy Shriver National Institute of Child Health and Human Development (NICHD), National Institutes of Health (NIH), Bethesda, Maryland 20892, USA. ²Division of Gene Structure and Function, Research Center for Genomic Medicine, Saitama Medical University, 1397-1 Yamane, Hidaka-shi, Saitama 350-1241, Japan. 
Received: 30 October 2012 Accepted: 21 November 2012

Published: 20 December 2012

\section{References}

1. Oppenheimer $\mathrm{JH}$ : Thyroid hormone action at the cellular level. Science 1979, 203:971-979.

2. Yen PM: Physiological and molecular basis of thyroid hormone action. Physiol Rev 2001, 81:1097-1142.

3. Canaris GJ, Manowitz NR, Mayor G, Ridgway EC: The Colorado thyroid disease prevalence study. Arch Intern Med 2000, 160:526-534.

4. Franklyn JA, Gammage MD: Thyroid disease: Effects on cardiovascular function. TEM 1996, 7:50-54.

5. Silva JE: Thyroid hormone control of thermogenesis and energy balance. Thyroid 1995, 5:481-492.

6. Freake $\mathrm{HC}$, Oppenheimer $\mathrm{JH}$ : Thermogenesis and thyroid function. Annu Rev Nutr 1995, 15:263-291.

7. Hetzel BS: The story of iodine deficiency: An international challenge in nutrition. Oxford: Oxford University Press; 1989.

8. Porterfield SP, Hendrich CE: The role of thyroid hormones in prenatal and neonatal neurological development-current perspectives. Endocr Rev 1993, 14:94-106.

9. Gilbert LI, Tata JR, Atkinson BG: Metamorphosis: Post-embryonic reprogramming of gene expression in amphibian and insect cells. New York: Academic Press; 1996.

10. Shi Y-B: Amphibian Metamorphosis: From morphology to molecular biology. New York: John Wiley \& Sons, Inc.; 1999.

11. Gudernatch JF: Feeding experiments on tadpoles. I. The influence of specific organs given as food on growth and differentiation: a contribution to the knowledge of organs with internal secretion. Arch Entwicklungsmech Org 1912, 35:457-483.

12. Tata JR: Gene expression during metamorphosis: an ideal model for post-embryonic development. BioEssays 1993, 15:239-248.

13. Davis PJ, Davis FB: Nongenomic actions of thyroid hormone. Thyroid 1996, 6:497-504

14. Shi Y-B, Wong J, Puzianowska-Kuznicka M, Stolow M: Tadpole competence and tissue-specific temporal regulation of amphibian metamorphosis: roles of thyroid hormone and its receptors. BioEssays 1996, 18:391-399.

15. Davis PJ, Davis FB: Nongenomic actions of thyroid hormone on the heart. Thyroid 2002, 12:459-466.

16. Parkison C, Ashizawa K, McPhie P, Lin KH, Cheng SY: The monomer of pyruvate kinase, subtype $M 1$, is both a kinase and a cytosolic thyroid hormone binding protein. Biochem Biophys Res Commun 1991, 179:668-674.

17. Shi Y-B, Liang VC-T, Parkison C, Cheng S-Y: Tissue-dependent developmental expression of a cytosolic thyroid hormone protein gene in Xenopus: its role in the regulation of amphibian metamorphosis. FEBS Lett 1994, 355:61-64.

18. Bassett JH, Harvey CB, Williams GR: Mechanisms of thyroid hormone receptor-specific nuclear and extra nuclear actions. Mol Cell Endocrinol 2003, 213:1-11.

19. Davis PJ, Davis FB, Cody V: Membrane receptors mediating thyroid hormone action. Trends Endocrinol Metab 2005, 16:429-435.

20. Storey NM, Gentile S, Ullah H, Russo A, Muessel M, Erxleben C, Armstrong DL: Rapid signaling at the plasma membrane by a nuclear receptor for thyroid hormone. Proc Natl Acad Sci U S A 2006, 103:5197-5201.

21. Guigon CJ, Cheng SY: Novel non-genomic signaling of thyroid hormone receptors in thyroid carcinogenesis. Mol Cell Endocrinol 2009, 308:63-69.

22. Laudet V, Gronemeyer H: The nuclear receptor FactsBook. San Diego: Academic Press; 2002.

23. Cheng SY: Thyroid hormone receptor mutations and disease: beyond thyroid hormone resistance. Trends Endocrinol Metab 2005, 16:176-182.

24. Sakurai A, Takeda K, Ain K, Ceccarelli P, Nakai A, Seino S, Bell Gl, Refetoff S, DeGroot LJ: Generalized resistance to thyroid hormone associated with a mutation in the ligand-binding domain of the human thyroid hormone receptor beta. Proc Natl Acad Sci U S A 1989, 86:8977-8981.

25. Chatterjee VKK, Nagaya T, Madison LD, Patta S, Rantoumis A, Jameson JL: Thyroid hormone resistance syndrome: Inhibition of normal receptor function by mutant thyroid hormone receptors. J Clin Invest 1991, 87:1977-1984

26. Bochukova E, Schoenmakers N, Agostini M, Schoenmakers E, Rajanayagam O, Keogh JM, Henning E, Reinemund J, Gevers E, Sarri M, et al: A mutation in the thyroid hormone receptor alpha gene. N Engl J Med 2012, 366:243-249.
27. van Mullem A, van Heerebeek R, Chrysis D, Visser E, Medici M, Andrikoula M, Tsatsoulis A, Peeters R, Visser TJ: Clinical phenotype and mutant TRalpha1. N Engl J Med 2012, 366:1451-1453.

28. Flamant F, Samarut J: Thyroid hormone receptors: Lessons from knockout and knock-in mutant mice. Trends in Endocrinology and metabolism 2003, 14:85-90.

29. Schreiber AM, Das B, Huang H, Marsh-Armstrong N, Brown DD: Diverse developmental programs of Xenopus laevis metamorphosis are inhibited by a dominant negative thyroid hormone receptor. PNAS 2001, 98:10739-10744.

30. Brown DD, Cai L: Amphibian metamorphosis. Dev Bio/ 2007, 306:20-33.

31. Buchholz DR, Hsia VS-C, Fu L, Shi Y-B: A dominant negative thyroid hormone receptor blocks amphibian metamorphosis by retaining corepressors at target genes. Mol Cell Biol 2003, 23:6750-6758.

32. Buchholz DR, Tomita A, Fu L, Paul BD, Shi Y-B: Transgenic analysis reveals that thyroid hormone receptor is sufficient to mediate the thyroid hormone signal in frog metamorphosis. Mol Cell Biol 2004, 24:9026-9037.

33. Buchholz DR, Paul BD, Fu L, Shi YB: Molecular and developmental analyses of thyroid hormone receptor function in Xenopus laevis, the African clawed frog. Gen Comp Endocrinol 2006, 145:1-19.

34. Shi Y-B: Dual functions of thyroid hormone receptors in vertebrate development: the roles of histone-modifying cofactor complexes. Thyroid 2009, 19:987-999.

35. Nakajima K, Yaoita Y: Dual mechanisms governing muscle cell death in tadpole tail during amphibian metamorphosis. Dev Dyn 2003, 227:246-255.

36. Denver RJ, Hu F, Scanlan TS, Furlow JD: Thyroid hormone receptor subtype specificity for hormone-dependent neurogenesis in Xenopus laevis. Dev Biol 2009, 326:155-168.

37. Bagamasbad P, Howdeshell KL, Sachs LM, Demeneix BA, Denver RJ: A role for basic transcription element-binding protein 1 (BTEB1) in the autoinduction of thyroid hormone receptor beta. J Biol Chem 2008, 283:2275-2285.

38. Schreiber AM, Mukhi S, Brown DD: Cell-cell interactions during remodeling of the intestine at metamorphosis in Xenopus laevis. Dev Biol 2009, 331:89-98

39. Sachs LM, Damjanovski S, Jones PL, Li Q, Amano T, Ueda S, Shi YB, Ishizuya-Oka A: Dual functions of thyroid hormone receptors during Xenopus development. Comp Biochem Physiol B Biochem Mol Biol 2000, 126:199-211.

40. Shi Y-B: Molecular biology of amphibian metamorphosis: A new approach to an old problem. Trends Endocrinol Metab 1994, 5:14-20.

41. Lazar MA: Thyroid hormone receptors: multiple forms, multiple possibilities. Endocr Rev 1993, 14:184-193.

42. Mangelsdorf DJ, Thummel C, Beato M, Herrlich P, Schutz G, Umesono K, Blumberg B, Kastner P, Mark M, Chambon P: The nuclear receptor superfamily: the second decade. Cell 1995, 83:835-839.

43. Tsai MJ, O'Malley BW: Molecular mechanisms of action of steroid/thyroid receptor superfamily members. Ann Rev Biochem 1994, 63:451-486.

44. Wong J, Shi YB, Wolffe AP: A role for nucleosome assembly in both silencing and activation of the Xenopus TR beta A gene by the thyroid hormone receptor. Genes Dev 1995, 9:2696-2711.

45. Wong J, Shi Y-B, Wolffe AP: Determinants of chromatin disruption and transcriptional regulation instigated by the thyroid hormone receptor: hormone-regulated chromatin disruption is not sufficient for transcriptinal activation. EMBO J 1997, 16:3158-3171.

46. Wong J, Patterton D, Imhof D, Guschin D, Shi Y-B, Wolffe AP: Distinct requirements for chromatin assembly in transcriptional repression by thyroid hormone receptor and histone deacetylase. EMBO J 1998 17:520-534.

47. McKenna NJ, O'Malley BW: Combinatorial control of gene expression by nuclear receptors and coregulators. Cell 2002, 108:465-474.

48. Horlein AJ, Naar AM, Heinzel T, Torchia J, Gloss B, Kurokawa R, Ryan A, Kamei $Y$, Soderstrom M, Glass CK, et al: Ligand-independent repression by the thyroid hormone receptor mediated by a nuclear receptor co-repressor. Nature 1995, 377:397-404.

49. Chen JD, Evans RM: A transcriptional co-repressor that interacts with nuclear hormone receptors. Nature 1995, 377:454-457.

50. Burke LJ, Baniahmad A: Co-repressors 2000. FASEB J 2000, 14:1876-1888.

51. Jones PL, Shi Y-B: N-CoR-HDAC corepressor complexes: Roles in transcriptional regulation by nuclear hormone receptors. In Current Topics in Microbiology and Immunology: Protein Complexes that Modify Chromatin. 274th edition. Edited by Workman JL. Berlin: Springer-Verlag; 2003:237-268. 
52. Glass $\mathrm{CK}$, Rosenfeld MG: The coregulator exchange in transcriptional functions of nuclear receptors. Genes Dev 2000, 14:121-141.

53. Ito M, Roeder RG: The TRAP/SMCC/Mediator complex and thyroid hormone receptor function. Trends Endocrinol Metab 2001, 12:127-134.

54. Zhang J, Lazar MA: The mechanism of action of thyroid hormones. Annu Rev Physiol 2000, 62:439-466.

55. Huang Z-Q, Li J, Sachs LM, Cole PA, Wong J: A role for cofactor-cofactor and cofactor-histone interactions in targeting $\mathrm{p} 300$, SWI/SNF and Mediator for transcription. EMBO J 2003, 22:2146-2155.

56. McKenna NJ, O'Malley BW: Nuclear receptors, coregulators, ligands, and selective receptor modulators: making sense of the patchwork quilt. Ann N Y Acad Sci 2001, 949:3-5.

57. Rachez C, Freedman LP: Mediator complexes and transcription. Curr Opin Cell Biol 2001, 13:274-280.

58. Chen H, Lin RJ, Schiltz RL, Chakravarti D, Nash A, Nagy L, Privalsky ML, Nakatani Y, Evans RM: Nuclear receptor coactivator ACTR is a novel histone acetyltransferase and forms a multimeric activation complex with P/CAF and CBP/p300. Cell 1997, 90:569-580.

59. Demarest SJ, Martinez-Yamout M, Chung J, Chen H, Xu W, Dyson HJ, Evans RM, Wright PE: Mutual synergistic folding in recruitment of CBP/p300 by p160 nuclear receptor coactivators. Nature 2002, 415:549-553.

60. Onate SA, Tsai SY, Tsai MJ, O'Malley BW: Sequence and characterization of a coactivator for the steroid hormone receptor superfamily. Science 1995, 270:1354-1357.

61. Meng X, Yang YF, Cao X, Govindan MV, Shuen M, Hollenberg AN, Mymryk JS, Walfish PG: Cellular context of coregulator and adaptor proteins regulates human adenovirus 5 early region $1 \mathrm{~A}$-dependent gene activation by the thyroid hormone receptor. Mol Endocrinol 2003, 17:1095-1105.

62. Wahlstrom GM, Vennstrom B, Bolin MB: The adenovirus E1A protein is a potent coactivator for thyroid hormone receptors. Mol Endocrinol 1999 13:1119-1129.

63. Sato Y, Ding A, Heimeier RA, Yousef AF, Mymryk JS, Walfish PG, Shi Y-B: The adenoviral E1A protein displaces corepressors and relieves gene repression by unliganded thyroid hormone receptors in vivo. Cell Res 2009, 19:783-792.

64. Perissi V, Jepsen K, Glass CK, Rosenfeld MG: Deconstructing repression: evolving models of co-repressor action. Nat Rev Genet 2010, 11:109-123.

65. O'Malley BW, Malovannaya A, Qin J: Minireview: nuclear receptor and coregulator proteomics-2012 and beyond. Mol Endocrinol 2012, 26:1646-1650.

66. Bulynko YA, O'Malley BW: Nuclear receptor coactivators: structural and functional biochemistry. Biochemistry 2011, 50:313-328.

67. McKenna NJ, Cooney AJ, DeMayo FJ, Downes M, Glass CK, Lanz RB, Lazar MA, Mangelsdorf DJ, Moore DD, Qin J, et al: Minireview: Evolution of NURSA, the Nuclear Receptor Signaling Atlas. Mol Endocrinol 2009, 23:740-746.

68. Yoon H-G, Chan DW, Huang ZQ, Li J, Fondell JD, Qin J, Wong J: Purification and functional characterization of the human $\mathrm{N}-\mathrm{CoR}$ complex: the roles of HDAC3, TBL1 and TBLR1. EMBO J 2003, 22:1336-1346.

69. Zhang J, Kalkum M, Chait BT, Roeder RG: The N-CoR-HDAC3 nuclear receptor corepressor complex inhibits the JNK pathway through the integral subunit GPS2. Mol Cell 2002, 9:611-623.

70. Ishizuka T, Lazar MA: The N-CoR/histone deacetylase 3 complex is required for repression by thyroid hormone receptor. Mol Cell Biol 2003, 23:5122-5131

71. Guenther MG, Lane WS, Fischle W, Verdin E, Lazar MA, Shiekhattar R: A core SMRT corepressor complex containing HDAC3 and TBL1, a WD40-repeat protein linked to deafness. Genes \& Devel 2000, 14:1048-1057.

72. Li J, Wang J, Wang J, Nawaz Z, Liu JM, Qin J, Wong J: Both corepressor proteins SMRT and N-CoR exist in large protein complexes containing HDAC3. EMBO I 2000, 19:4342-4350.

73. Stewart D, Tomita A, Shi YB, Wong J: Chromatin immunoprecipitation for studying transcriptional regulation in Xenopus oocytes and tadpoles. Methods Mol Biol 2006, 322:165-181

74. Stewart MD, Li J, Wong J: Relationship between histone H3 lysine 9 methylation, transcription repression, and heterochromatin protein 1 recruitment. Mol Cell Biol 2005, 25:2525-2538.

75. Li J, Lin Q, Yoon HG, Huang ZQ, Strahl BD, Allis CD, Wong J: Involvement of histone methylation and phosphorylation in regulation of transcription by thyroid hormone receptor. Mol Cell Biol 2002, 22:5688-5697.
76. Jones PL, Sachs LM, Rouse N, Wade PA, Shi YB: Multiple N-CoR complexes contain distinct histone deacetylases. J Biol Chem 2001, 276:8807-8811.

77. Tomita A, Buchholz DR, Shi Y-B: Recruitment of N-CoR/SMRT-TBLR1 corepressor complex by unliganded thyroid hormone receptor for gene repression during frog development. Mol Cell Biol 2004, 24:3337-3346.

78. Heimeier RA, Hsia VS-C, Shi Y-B: Participation of BAF57 and BRG1Containing Chromatin Remodeling Complexes in Thyroid HormoneDependent Gene Activation during Vertebrate Development. Mol Endocrinol 2008, 22:1065-1077.

79. Sheppard HM, Harries JC, Hussain S, Bevan C, Heery DM: Analysis of the steroid receptor coactivator 1 (SRC1)-CREB binding protein interaction interface and its importance for the function of SRC1. Mol Cell Biol 2001, 21:39-50.

80. Li J, O'Malley BW, Wong J: p300 requires its histone acetyltransferase activity and SRC-1 interaction domain to facilitate thyroid hormone receptor activation in chromatin. Mol And Cell Biol 2000, 20:2031-2042.

81. Torchia J, Rose DW, Inostroza J, Kamei Y, Westin S, Glass CK, Rosenfeld MG: The transcriptional co-activator $\mathrm{p} / \mathrm{CIP}$ binds $\mathrm{CBP}$ and mediates nuclear-receptor function. Nature 1997, 387:677-684.

82. Chen D, Ma H, Hong H, Koh SS, Huang SM, Schurter BT, Aswad DW, Stallcup MR: Regulation of transcription by a protein methyltransferase. Science 1999, 284:2174-2177.

83. Koh SS, Chen DG, Lee YH, Stallcup MR: Synergistic enhancement of nuclear receptor function by 160 coactivators and two coactivators with protein methyltransferase activities. J Biol Chem 2001, 276:1089-1098.

84. Matsuda H, Paul BD, Choi CY, Hasebe T, Shi Y-B: Novel functions of protein arginine methyltransferase 1 in thyroid hormone receptor-mediated transcription and in the regulation of metamorphic rate in Xenopus laevis. Mol Cell Biol 2009, 29:745-757.

85. Matsuda H, Paul BD, Choi CY, Shi Y-B: Contrasting effects of two alternative splicing forms of coactivator-associated arginine methyltransferase 1 on thyroid hormone receptor-mediated transcription in Xenopus laevis. Mol Endocrinology 2007, 21:1082-1094.

86. Havis E, Sachs LM, Demeneix BA: Metamorphic T3-response genes have specific co-regulator requirements. EMBO Reports 2003, 4:883-888.

87. Paul BD, Fu L, Buchholz DR, Shi Y-B: Coactivator recruitment is essential for liganded thyroid hormone receptor to initiate amphibian metamorphosis. Mol Cell Biol 2005, 25:5712-5724.

88. Paul BD, Buchholz DR, Fu L, Shi Y-B: Tissue- and gene-specific recruitment of steroid receptor coactivator- 3 by thyroid hormone receptor during development. J Biol Chem 2005, 280:27165-27172.

89. Paul BD, Buchholz DR, Fu L, Shi Y-B: SRC-p300 coactivator complex is required for thyroid hormone induced amphibian metamorphosis. J Biol Chem 2007, 282:7472-7481.

90. Xu J, Liao L, Ning G, Yoshida-Komiya H, Deng C, O'Malley BW: The steroid receptor coactivator SRC-3 (p/CIP/RAC3/AIB1/ACTR/TRAM-1) is requried for normal growth, puberty, female reproductive function, and mammary gland development. Proc Nat Acad Sci USA 2000, 97:6379-6384.

91. Gehin M, Mark M, Dennefeld C, Dierich A, Gronemeyer H, Chambon P: The function of TIF2/GRIP1 in mouse reproduction is distinct from those of SRC-1 and p/CIP. Mol Cell Biol 2002, 22:5923-5927.

92. Yao TP, Oh SP, Fuchs M, Zhou ND, Ch'ng LE, Newsome D, Bronson RT, Li E, Livingston DM, Eckner R: Gene dosage-dependent embryonic development and proliferation defects in mice lacking the transcriptional integrator p300. Cell 1998, 93:361-372.

93. Wang Z, Rose DW, Hermanson O, Liu F, Herman T, Wu W, Szeto D, Gleiberman A, Krones A, Pratt K, et al: Regulation of somatic growth by the p160 coactivator p/CIP. Proc Nat Acad Sci USA 2000, 97:13549-13554.

94. Jepsen K, Hermanson O, Onami TM, Gleiberman AS, Lunyak V, McEvilly RJ, Kurokawa R, Kumar V, Liu F, Seto E, et al: Combinatorial roles of the nuclear receptor corepressor in transcription and development [In Process Citation]. Cell 2000, 102:753-763.

95. Ito M, Yuan CX, Okano HJ, Darnell RB, Roeder RG: Involvement of the TRAP220 component of the TRAP/SMCC coactivator complex in embryonic development and thyroid hormone action. Mol Cell 2000 5:683-693.

96. Weiss RE, XU J, Ning G, Pohlenz J, O'Malley BW, Refetoff S: Mice deficient in the steroid receptor co-activator 1 (SRC-1) are resistant to thyroid hormone. EMBO f 1999, 18:1900-1904. 
97. Astapova I, Lee $L$, Morales C, Tauber S, Bilban M, Hollenberg AN: The nuclear corepressor, $\mathrm{NCoR}$, regulates thyroid hormone action in vivo. Proc Natl Acad Sci 2008, 105:19544-19549.

98. You SH, Liao X, Weiss RE, Lazar MA: The interaction between nuclear receptor corepressor and histone deacetylase 3 regulates both positive and negative thyroid hormone action in vivo. Mol Endocrinol 2010, 24:1359-1367.

99. Pei L, Leblanc M, Barish G, Atkins A, Nofsinger R, Whyte J, Gold D, He M, Kawamura K, Li HR, et al: Thyroid hormone receptor repression is linked to type I pneumocyte-associated respiratory distress syndrome. Nat Med 2011, 17:1466-1472

100. Sachs LM, Jones PL, Havis E, Rouse N, Demeneix BA, Shi Y-B: N-CoR recruitment by unliganded thyroid hormone receptor in gene repression during Xenopus laevis development. Mol Cell Biol 2002, 22:8527-8538.

101. Sato Y, Buchholz DR, Paul BD, Shi Y-B: A role of unliganded thyroid hormone receptor in postembryonic development in Xenopus laevis. Mech Dev 2007, 124:476-488.

102. Paul BD, Shi Y-B: Distinct expression profiles of transcriptional coactivators for thyroid hormone receptors during Xenopus laevis metamorphosis. Cell Research 2003, 13:459-464.

103. Perlman AJ, Stanley F, Samuels HH: Thyroid hormone nuclear receptor. Evidence for multimeric organization in chromatin. J Biol Chem 1982, 257:930-938.

104. Wong J, Shi Y-B: Coordinated regulation of and transcriptional activation by Xenopus thyroid hormone and retinoid X receptors. J Biol Chem 1995 , 270:18479-18483.

105. Hsia VS-C, Shi Y-B: Chromatin Disruption and Histone Acetylation in the Regulation of HIV-LTR by Thyroid Hormone Receptor. Mol Cell Biol 2002, 22:4043-4052

106. Amaya E, Offield MF, Grainger RM: Frog genetics: Xenopus tropicalis jumps into the future. Trends Genet 1998, 14:253-255.

107. Hellsten U, Harland RM, Gilchrist MJ, Hendrix D, Jurka J, Kapitonov V, Ovcharenko I, Putnam NH, Shu S, Taher L, et al: The genome of the Western clawed frog Xenopus tropicalis. Science 2010, 328:633-636.

108. McAvoy JW, Dixon KE: Cell proliferation and renewal in the small intestinal epithelium of metamorphosing and adult Xenopus laevis. J Exp Zool 1977, 202:129-138

109. Shi YB, Hasebe T, Fu L, Fujimoto K, Ishizuya-Oka A: The development of the adult intestinal stem cells: Insights from studies on thyroid hormone-dependent amphibian metamorphosis. Cell Biosci 2011, 1:30.

110. Shi Y-B, Ishizuya-Oka A: Biphasic intestinal development in amphibians: Embryogensis and remodeling during metamorphosis. Current Topics in Develop Biol 1996, 32:205-235.

111. Ishizuya-Oka A, Shi YB: Evolutionary insights into postembryonic development of adult intestinal stem cells. Cell Biosci 2011, 1:37.

112. Sun G, Shi Y-B: Thyroid hormone regulation of adult intestinal stem cell development: Mechanisms and evolutionary conservations. Int J Biol Sci 2012, 8:1217-1224.

113. Matsuura K, Fujimoto K, Fu L, Shi Y-B: Liganded thyroid hormone receptor induces nucleosome removal and histone modifications to activate transcription during larval intestinal cell death and adult stem cell development. Endocrinology 2012, 153:961-972.

114. Li J, Lin Q, Wang W, Wade P, Wong J: Specific targeting and constitutive association of histone deacetylase complexes during transcriptional repression. Genes Dev 2002, 16:687-692.

115. Sharma D, Fondell JD: Ordered recruitment of histone acetyltransferases and the TRAP/Mediator complex to thyroid hormone-responsive promoters in vivo. Proc Natl Acad Sci U S A 2002, 99:7934-7939.

116. Liu Y, Xia X, Fondell JD, Yen PM: Thyroid hormone-regulated target genes have distinct patterns of coactivator recruitment and histone acetylation. Mol Endocrinol 2006, 20:483-490.

117. Sachs $L M$, Shi Y-B: Targeted chromatin binding and histone acetylation in vivo by thyroid hormone receptor during amphibian development. PNAS 2000, 97:13138-13143.

118. Sachs LM, Amano T, Shi YB: An essential role of histone deacetylases in postembryonic organ transformations in Xenopus laevis. Int $\mathrm{J}$ Mol Med 2001, 8:595-601.

119. Sachs LM, Amano T, Rouse N, Shi YB: Involvement of histone deacetylase at two distinct steps in gene regulation during intestinal development in Xenopus laevis. Dev Dyn 2001, 222:280-291.
120. Bilesimo P, Jolivet P, Alfama G, Buisine N, Le Mevel S, Havis E, Demeneix BA, Sachs LM: Specific Histone Lysine 4 Methylation Patterns Define TR-Binding Capacity and Differentiate Direct T3 Responses. Mol Endocrinol 2011, 25:225-237.

121. Grimaldi A, Buisine N, Miller T, Shi YB, Sachs LM: Mechanisms of thyroid hormone receptor action during development: Lessons from amphibian studies. Biochim Biophys Acta 2012, In press.

122. Matsuura K, Fujimoto K, Das B, Fu L, Lu CD, Shi YB: Histone H3K79 methyltransferase Dot $1 \mathrm{~L}$ is directly activated by thyroid hormone receptor during Xenopus metamorphosis. Cell Biosci 2012, 2:25.

123. Fujimoto K, Matsuura K, Hu-Wang E, Lu R, Shi YB: Thyroid Hormone Activates Protein Arginine Methyltransferase 1 Expression by Directly Inducing c-Myc Transcription during Xenopus Intestinal Stem Cell Development. J Biol Chem 2012, 287:10039-10050.

124. Matsuda H, Shi YB: An essential and evolutionarily conserved role of protein arginine methyltransferase 1 for adult intestinal stem cells during postembryonic development. Stem Cells 2010, 28:2073-2083.

125. Young JJ, Cherone JM, Doyon Y, Ankoudinova I, Faraji FM, Lee AH, Ngo C, Guschin DY, Paschon DE, Miller JC, et al: Efficient targeted gene disruption in the soma and germ line of the frog Xenopus tropicalis using engineered zinc-finger nucleases. Proc Natl Acad Sci U S A 2011, 108:7052-7057.

126. Lei $Y$, Guo X, Liu Y, Cao Y, Deng Y, Chen X, Cheng CH, Dawid IB, Chen Y, Zhao $\mathrm{H}$ : Efficient targeted gene disruption in Xenopus embryos using engineered transcription activator-like effector nucleases (TALENs). Proc Natl Acad Sci U S A 2012, 109:17484-17489.

127. Hsia VS-C, Wang H, Shi Y-B: Involvement of Chromatin and Histone Acetylation in the Regulation of HIV-LTR by Thyroid Hormone Receptor. Cell Research 2001, 11:8-16.

doi:10.1186/2045-3701-2-42

Cite this article as: Shi et al:: Thyroid hormone receptor actions on transcription in amphibia: The roles of histone modification and chromatin disruption. Cell \& Bioscience 2012 2:42.

\section{Submit your next manuscript to BioMed Central and take full advantage of:}

- Convenient online submission

- Thorough peer review

- No space constraints or color figure charges

- Immediate publication on acceptance

- Inclusion in PubMed, CAS, Scopus and Google Scholar

- Research which is freely available for redistribution 